\title{
Antibacterial activities and structure- activity relationships of a panel of 48 compounds from Kenyan plants against multidrug resistant phenotypes
}

Leonidah K. Omosa 1,3*, Jacob O. Midiwo', Armelle T. Mbaveng ${ }^{2}$, Simplice B. Tankeo², Jackson A. Seukep², Igor K. Voukeng ${ }^{2}$, Joachim K. Dzotam², John Isemeki ${ }^{1}$, Solomon Derese ${ }^{1}$, Ruth A. Omolle ${ }^{1}$, Thomas Efferth ${ }^{3}$ and Victor Kuete $2^{2^{*}}$

\begin{abstract}
In the current study forty eight compounds belonging to anthraquinones, naphthoquinones, benzoquinones, flavonoids (chalcones and polymethoxylated flavones) and diterpenoids (clerodanes and kauranes) were explored for their antimicrobial potential against a panel of sensitive and multi-drug resistant Gram-negative and Gram-positive bacteria. The minimal inhibitory concentration (MIC) determinations on the tested bacteria were conducted using modified rapid INT colorimetric assay. To evaluate the role of efflux pumps in the susceptibility of Gram-negative bacteria to the most active compounds, they were tested in the presence of phenylalanine arginine $\beta$-naphthylamide (PABN) (at $30 \mu \mathrm{g} / \mathrm{mL}$ ) against selected multidrug resistance (MDR) bacteria. The anthraquinone, emodin, naphthaquinone, plumbagin and the benzoquinone, rapanone were active against methicillin resistant Staphylococcus aureus (MRSA) strains of bacteria with MIC values ranging from 2 to $128 \mu \mathrm{g} / \mathrm{mL}$. The structure activity relationships of benzoquinones against the MDR Gram-negative phenotype showed antibacterial activities increasing with increase in side chain length. In the chalcone series the presence of a hydroxyl group at C $3^{\prime}$ together with a methoxy group and a second hydroxyl group in meta orientation in ring B of the chalcone skeleton appeared to be necessary for minimal activities against MRSA. In most cases, the optimal potential of the active compounds were not attained as they were extruded by bacterial efflux pumps. However, the presence of the PABN significantly increased the antibacterial activities of emodin against Gram-negative MDR E. coli AG102, 100ATet; K. pneumoniae KP55 and KP63 by >4-64 g/mL. The antibacterial activities were substantially enhanced and were higher than those of the standard drug, chloramphenicol. These data clearly demonstrate that the active compounds, having the necessary pharmacophores for antibacterial activities, including some quinones and chalcones are substrates of bacterial efflux pumps and therefore should be combined to efflux pump inhibitors in the fight against MDR bacterial infections.
\end{abstract}

Keywords: Anthraquinones, Benzoquinones, Chalcones, Antibacterial activities, Multidrug resistance, Efflux pump inhibitor

\footnotetext{
*Correspondence: Ikerubo@uonbi.ac.ke; kuetevictor@yahoo.fr

${ }^{1}$ Department of Chemistry, School of Physical Sciences, University

of Nairobi, P. O. Box 30197-00100, Nairobi, Kenya

2 Department of Biochemistry, Faculty of Science, University of Dschang,

Dschang, Cameroon

Full list of author information is available at the end of the article
} 


\section{Background}

Multidrug resistance (MDR) in bacteria is usually mediated by the expression of efflux pumps or porins involved in transport, by the expression of mutated genes coding for specific drug targets or specific enzymatic barriers. As a matter of fact, MDR remains a major obstacle hindering successful antibacerial chemotherapy (Alekshun and Levy 2007; Davin-Regli et al. 2008; Nikaido 2009).

One way of tackling the emergence of MDR is to diversify the chemical structures of anti-microbial drugs to which resistance has developed in order to extend their lifespan (De Clercq 2001; Poole 2001; Jeu et al. 2003). Alternatively, the compounds exhibiting modest to significant antibacterial activities against MDR phenotypes, could be used in combination with the efflux inhibitors, in order to improve on the accumulation of the drug in the cells for optimal activities (Kuete et al. 2011). It is not surprising that in response to anti-microbial resistance, major pharmaceutical companies have concentrated their efforts on improving chemotherapeutic agents in established drug classes (Taylor et al. 2002). However, with the portfolio of antimicrobials currently available, most of the lead structures of current drugs have already been explored. Today, large-scale empirical screening of synthetic, semi-synthetic and natural chemical entities in chemical libraries for anti-microbial activities is investigated (Kimberlin and Whitley 1996). The compounds of interest for the development of novel drugs include those that target different proteins or biochemical processes compared to those in current use and those that inhibit bacterial efflux pumps (Kuete et al. 2011). Natural products have been a particularly rich source of antiinfective agents, yielding, for example, the penicillins in 1940, the tetracyclines in 1948 and the glycopeptides in 1955 (Silver and Bostian 1990). In the current study the antibacterial activities of compounds from several families (anthraquinones, naphthoquinones, benzoquinones, chalcones, flavones, flavanones, clerodane, and kaurane diterpenoids) were determined against different bacterial strains expressing MDR phenotypes. Furthermore, the chemical moieties relevant for pharmacophore binding were analyzed by their structure activity relationships (SAR) studies of related compounds.

\section{Results and discussion}

\section{Studied compounds}

The natural and modified compounds investigated in the current study were previously isolated from Kenyan plants (Figs. 1, 2). These included quinones; four anthraquinones namely; chrysophanol (1) (Fairbairn and ElMuhtadi 1972; Midiwo and Rukunga 1985; Zhang et al. 2012), emodin (2) (Munavu et al. 1984; Chang et al. 1996), 3,6,8-trihydroxy-1-methylanthraquinone-2-carboxylic acid; Me ester (3) (Mehandale et al. 1968; Dagne et al. 1996), aloesaponol I; (-)-form (4) (Yagi et al. 1978; Dagne et al. 1992; Midiwo et al. 1997), a naphthoquinones; 5-hydroxy-2-methyl-1,4-naphthalenedione, plumbagin (5) (Sidhu et al. 1968; Yuan and Chao 2007), thirteen related benzoquinones; 2,5-dihydroxy-3-ethyl2,5-cyclohexadiene-1,4-dione (6) (Khurana et al. 1972) and synthetic derivatives, 2,5-dihydroxy-3-propyl2,5-cyclohexadiene-1,4-dione (7), 2,5-dihydroxy-3-butyl2,5-cyclohexadiene-1,4-dione $\quad(8), \quad 2,5$-dihydroxy-3heptyl-2,5-cyclohexadiene-1,4-dione (9), 2,5-dihydroxy3-nonyl-2,5-cyclohexadiene-1,4-dione, homoembelin (10) (Murthy et al. 1965), 2,5-dihydroxy-3-tridecyl-2,5-cyclohexadiene-1,4-dione, rapanone (11) (Wouters and Verhecken 1987), 2,5-dihydroxy-3-pentadecyl-2,5-cyclohexadiene-1,4-dione (12) (Ogawa and Natori 1965, 1968a), 2-hydroxy-5-methoxy-3-undecyl-1,4-benzoquinone, 5-O-methylembelin (13) (Merian and Schlittler 1948), 2,5-dimethoxy-3-undecyl-1,4-benzoquinone, 2,5-di-O-dimethylembelin (2,5-dimethoxy3-undecyl-[1,4]-benzoquinone) (14) (Wu et al. 2009), 2,5-dihydroxy-3-methyl-6-(14-nonadecenyl)-1,4-benzoquinone, maesaquinone (15) (Ogawa and Natori 1965, 1968a; Ogawa and Natori 1968b; Manguro et al. 2003), 2,5 dimethoxy-6-(14-nonadecenyl)-1,4-benzoquinone (16), 1,2,4,5-tetraacetate-3-methyl-6-(14-nonadecenyl)cyclohexadi-2,5-diene (17), ardisiaquinone (18) (Yoshihir et al. 1968; Ogawa and Natori 1968b), flavonoids including six chalcones; $3^{\prime}, 5^{\prime}$-dihydroxy-1'-methoxychalcone (19), $1^{\prime}, 5^{\prime}$-dihydroxy-3'-methoxychalcone (20), $1^{\prime}, 3^{\prime}$-dihydroxy$2^{\prime}, 5^{\prime}$-dimethoxychalcone (21), $5^{\prime}$-hydroxy-1', $3^{\prime}$-dimethoxychalcone (22), $\quad 1^{\prime}, 3^{\prime}, 5^{\prime}$-trihydroxy-2'-methoxychalcone (23), 1,5-diacetate-3'-methoxychalcone (24) (Midiwo et al. 1990; 1992), ten polymethoxylated flavones and their semi-synthetic derivatives; 5,7-dihydroxy3,4-dimethoxyflavone (25), 3,5,4'-trihydroxy-7 methoxyflavone (26), 5,7-dihydroxy-3,6,4'-trimethoxyflavone (27), 5,4'-dihydroxy-3,7-dimethoxyflavone (28), 5-hydroxy3,7,4'-trimethoxyflavone (29) (Omosa et al. 2010), 3,5,6,7,4'-pentamethoxyflavone (30), 5-hydroxy-2', $3^{\prime}, 4^{\prime}$, $5^{\prime}$-tetramethoxyflavone (31), 5-hydroxy-7, $2^{\prime}, 3^{\prime}, 4^{\prime}, 5^{\prime}$ pentamethoxyflavone (32) (Juma et al. 2001), 5,7diacetate-3,6,4'-trimethoxyflavone (33) semi-synthetic derivative of 5,7-dihydroxy-3,6,4'-trimethoxyflavone (Omosa et al. 2010), 5,7-diacetate-3,4'-trimethoxyflavone (34) a semi-synthetic derivative of 5,7-dihydroxy3,4'-trimethoxyflavone; three flavanones; 5,4'-dihydroxy-7-methoxyflavanone (35) (Kerubo et al. 2013), 3,7-dihydroxy-5,8-dimethoxyflavanone (36), 5,7,4'trihydroxy-3'-prenylflavanone (37) (Nakahara et al. 2003); eleven diterpenoids, four clerodane type; dodonic acid (38), hautriwaic acid (39), 2 $\beta$-hydroxyhardwickiic acid (40), hautriwaic acid lactone (41) (Omosa et al. 
<smiles>[R]Cc1cc(O)c2c(c1)C(=O)c1cc([R2])c([R])c([R4])c1C2=O</smiles>

\begin{tabular}{l|llll} 
& $\mathrm{R}_{1}$ & $\mathrm{R}_{2}$ & $\mathrm{R}_{3}$ & $\mathrm{R}_{4}$ \\
\hline $\mathbf{1}$ & $\mathrm{Me}$ & $\mathrm{H}$ & $\mathrm{H}$ & $\mathrm{OH}$ \\
$\mathbf{2}$ & $\mathrm{Me}$ & $\mathrm{OH}$ & $\mathrm{H}$ & $\mathrm{OH}$ \\
$\mathbf{3}$ & $\mathrm{OH}$ & $\mathrm{OH}$ & COOMe & $\mathrm{Me}$
\end{tabular}<smiles>[R]OC1=C(C)C(=O)C([R2])=C([R2])C1=O</smiles>

\begin{tabular}{r|rrll} 
& $\mathrm{R}_{1}$ & $\mathrm{R}_{2}$ & $\mathrm{R}_{3}$ & $\mathrm{n}$ \\
\hline $\mathbf{6}$ & $\mathrm{H}$ & $\mathrm{H}$ & $\mathrm{H}$ & 1 \\
$\mathbf{7}$ & $\mathrm{H}$ & $\mathrm{H}$ & $\mathrm{H}$ & 2 \\
$\mathbf{8}$ & $\mathrm{H}$ & $\mathrm{H}$ & $\mathrm{H}$ & 3 \\
$\mathbf{9}$ & $\mathrm{H}$ & $\mathrm{H}$ & $\mathrm{H}$ & 6 \\
$\mathbf{1 0}$ & $\mathrm{H}$ & $\mathrm{H}$ & $\mathrm{H}$ & 8 \\
$\mathbf{1 1}$ & $\mathrm{H}$ & $\mathrm{H}$ & $\mathrm{H}$ & 12 \\
$\mathbf{1 2}$ & $\mathrm{H}$ & $\mathrm{H}$ & $\mathrm{H}$ & 14 \\
$\mathbf{1 3}$ & $\mathrm{H}$ & $\mathrm{H}$ & $\mathrm{Me}$ & 10 \\
$\mathbf{1 4}$ & $\mathrm{Me}$ & $\mathrm{H}$ & $\mathrm{Me}$ & 10 \\
$\mathbf{1 5}$ & $\mathrm{H}$ & $\mathrm{Me}$ & $\mathrm{H}$ & $-\left(\mathrm{CH}_{2}\right)_{12} \mathrm{CH}=\mathrm{CH}-\left(\mathrm{CH}_{2}\right)_{3}-(E)$ \\
$\mathbf{1 6}$ & $\mathrm{Me}$ & $\mathrm{H}$ & $\mathrm{Me}$ & $-\left(\mathrm{CH}_{2}\right)_{12} \mathrm{CH}=\mathrm{CH}-\left(\mathrm{CH}_{2}\right)_{3}-\left(E_{1}\right)$
\end{tabular}<smiles>COC(=O)c1c(O)cc2cc3c(c(O)c2c1C)C(=O)C[C@H](O)C3</smiles><smiles>CC1=CC(=O)c2c(O)cccc2C1=O</smiles>

5<smiles>CCCC/C=C\CCCCCCCCCCCCC1=C(OC(C)=O)[C@H](OC(C)=O)C(C)=C(OC(C)=O)[C@H]1OC(C)=O</smiles>

17

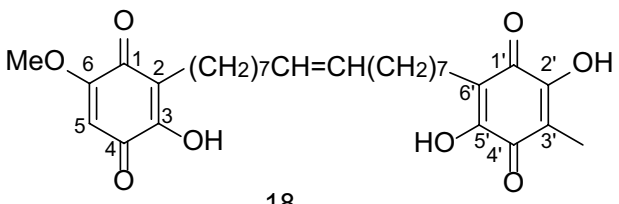

18<smiles>[R20]Oc1cc([R20])c(C(=O)/C=C/c2ccccc2)c([R20])c1[R]</smiles>

\begin{tabular}{l|llll} 
& $\mathrm{R}_{1}$ & $\mathrm{R}_{2}$ & $\mathrm{R}_{3}$ & $\mathrm{R}_{4}$ \\
\hline $\mathbf{1 9}$ & $\mathrm{H}$ & $\mathrm{H}$ & $\mathrm{H}$ & $\mathrm{Me}$ \\
$\mathbf{2 0}$ & $\mathrm{H}$ & $\mathrm{Me}$ & $\mathrm{H}$ & $\mathrm{H}$ \\
$\mathbf{2 1}$ & $\mathrm{Me}$ & $\mathrm{H}$ & $\mathrm{OMe}$ & $\mathrm{H}$ \\
$\mathbf{2 2}$ & $\mathrm{H}$ & $\mathrm{Me}$ & $\mathrm{H}$ & $\mathrm{Me}$ \\
$\mathbf{2 3}$ & $\mathrm{H}$ & $\mathrm{H}$ & OMe & $\mathrm{H}$ \\
$\mathbf{2 4}$ & $\mathrm{MeCO}$ & $\mathrm{Me}$ & $\mathrm{H}$ & $\mathrm{MeCO}$
\end{tabular}

Fig. 1 Chemical structures of the compounds tested; 1, chrysophanol; 2, emodin; 3, 3,6,8-trihydroxy-1-methylanthraquinone-2-carboxylic acid; Me; 4, aloesaponol I; 5, plumbagin; 6, benzoquinones; 2,5-dihydroxy-3-ethyl-2,5-cyclohexadiene-1,4-dione; 7, 2,5-dihydroxy-3-propyl-2,5-cyclohexadiene-1,4-dione; 8 , 2,5-dihydroxy-3-butyl-2,5-cyclohexadiene-1,4-dione; $\mathbf{9}, 2,5$-dihydroxy-3-heptyl-2,5-cyclohexadiene-1,4-dione; 10, homoembelin; 11, rapanone; 12, 2,5-dihydroxy-3-pentadecyl-2,5-cyclohexadiene-1,4-dione; 13, 5-O-methylembelin; 14, 2,5-di-O-dimethylembelin; 15, maesaquinone; 16, 2,5 dimethoxy-6-(14-nonadecenyl)-1,4-benzoquinone; 17, 1,2,4,5-tetraacetate-3-methyl-6-(14-nonadecenyl)-cyclohexadi-2,5-diene; 18, ardisiaquinone; 19, 3', $5^{\prime}$-dihydroxy-1'-methoxychalcone; 20, 1', $5^{\prime}$-dihydroxy-3'-methoxychalcone; 21, 1', $3^{\prime}$-dihydroxy-2',5'-dimethoxychalcone; 22 , 5'-hydroxy-1', 3'-dimethoxychalcone; 23, 1', 3',5'-trihydroxy-2'-methoxychalcone; 24, 1,5-diacetate-3'-methoxychalcone

2010), five trachylobane type; 6,17,19-trachylobanetriol; (ent-6 $\alpha$ )-form (42) (Juma et al. 2006), 2,6,19-trachylobanetriol; (ent-2 $\alpha, 6 \alpha)$-form (43) (Midiwo et al. 1997), 6,18,19-trachylobanetetrol; (ent-6 $\alpha$ )-form (44), 2,18,19-trachylobanetriol; (ent-2 $\alpha)$-form (45), 2,6,18, 19-trachylobanetetrol; (ent-2 $\beta, 6 \alpha$ )-form (46) (Juma et al. 2006) and two kaurane type; ent-kaur-16-en-2 $\alpha, 18,19$ triol (47), ent-kaur-16-en-18,19-diol (48) (Midiwo et al. 1997) Figs. 1 and 2.
The compounds were tested for their ability to prevent the growth of MDR and reference strains of Gramnegative bacteria, alone and for some of the active compounds, in the presence of the efflux pump inhibitor (EPI), PA $\beta \mathrm{N}$ (Table 2).

The antibacterial activity of compounds has been defined as significant when the MIC is below $10 \mu \mathrm{g} /$ $\mathrm{mL}$, moderate when $10<\mathrm{MIC}<100 \mu \mathrm{g} / \mathrm{mL}$ and low when MIC > $100 \mu \mathrm{g} / \mathrm{mL}$ (Kuete 2010; Kuete and Efferth 
<smiles>[R6]Oc1cc2oc(-c3cc([R9])c([R6])c([R])c3[R])c([R])c(=O)c2c([R2])c1[R]</smiles>

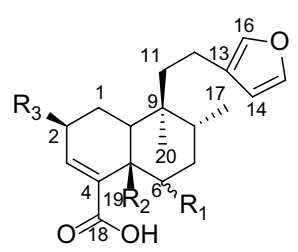

\begin{tabular}{l|llllllll} 
& $\mathrm{R}_{1}$ & $\mathrm{R}_{2}$ & $\mathrm{R}_{3}$ & $\mathrm{R}_{4}$ & $\mathrm{R}_{5}$ & $\mathrm{R}_{6}$ & $\mathrm{R}_{7}$ & $\mathrm{R}_{8}$ \\
\hline $\mathbf{2 5}$ & $\mathrm{OMe}$ & $\mathrm{H}$ & $\mathrm{H}$ & $\mathrm{H}$ & $\mathrm{H}$ & $\mathrm{Me}$ & $\mathrm{H}$ & $\mathrm{H}$ \\
$\mathbf{2 6}$ & $\mathrm{OH}$ & $\mathrm{H}$ & $\mathrm{H}$ & $\mathrm{Me}$ & $\mathrm{H}$ & $\mathrm{H}$ & $\mathrm{H}$ & $\mathrm{H}$ \\
$\mathbf{2 7}$ & $\mathrm{OMe}$ & $\mathrm{H}$ & $\mathrm{OMe}$ & $\mathrm{H}$ & $\mathrm{H}$ & $\mathrm{Me}$ & $\mathrm{H}$ & $\mathrm{H}$ \\
$\mathbf{2 8}$ & $\mathrm{Me}$ & $\mathrm{H}$ & $\mathrm{H}$ & $\mathrm{Me}$ & $\mathrm{H}$ & $\mathrm{H}$ & $\mathrm{H}$ & $\mathrm{H}$ \\
$\mathbf{2 9}$ & $\mathrm{OMe}$ & $\mathrm{H}$ & $\mathrm{H}$ & $\mathrm{Me}$ & $\mathrm{H}$ & $\mathrm{Me}$ & $\mathrm{H}$ & $\mathrm{H}$ \\
$\mathbf{3 0}$ & $\mathrm{OMe}$ & $\mathrm{Me}$ & $\mathrm{OMe}$ & $\mathrm{Me}$ & $\mathrm{H}$ & $\mathrm{Me}$ & $\mathrm{H}$ & $\mathrm{H}$ \\
$\mathbf{3 1}$ & $\mathrm{H}$ & $\mathrm{H}$ & $\mathrm{H}$ & $\mathrm{H}$ & $\mathrm{OMe}$ & $\mathrm{Me}$ & $\mathrm{OMe}$ & $\mathrm{OMe}$ \\
$\mathbf{3 2}$ & $\mathrm{H}$ & $\mathrm{H}$ & $\mathrm{H}$ & $\mathrm{Me}$ & $\mathrm{OMe}$ & $\mathrm{Me}$ & $\mathrm{OMe}$ & $\mathrm{OMe}$ \\
$\mathbf{3 3}$ & $\mathrm{OMe}$ & $\mathrm{COMe}$ & $\mathrm{OMe}$ & $\mathrm{COMe}$ & $\mathrm{H}$ & $\mathrm{Me}$ & $\mathrm{H}$ & $\mathrm{H}$ \\
$\mathbf{3 4}$ & $\mathrm{OMe}$ & COMe & $\mathrm{H}$ & COMe & $\mathrm{H}$ & $\mathrm{Me}$ & $\mathrm{H}$ & $\mathrm{H}$
\end{tabular}

\begin{tabular}{l|lll} 
& $\mathrm{R}_{1}$ & $\mathrm{R}_{2}$ & $\mathrm{R}_{3}$ \\
\hline $\mathbf{3 8}$ & $-\mathrm{OH}$ & $\mathrm{H}$ & $\mathrm{H}$ \\
$\mathbf{3 9}$ & $\mathrm{H}$ & $\mathrm{CH}_{2} \mathrm{OH}$ & $\mathrm{H}$ \\
$\mathbf{4 0}$ & $\mathrm{H}$ & $\mathrm{H}$ & $\mathrm{OH}$
\end{tabular}<smiles>[R6]Oc1cc([R20])c2c(c1[R])O[C@H](c1cc([R7])c([R6])c([R])c1)C([R7])C2=O</smiles>

\begin{tabular}{l|lllllll} 
& $\mathrm{R}_{1}$ & $\mathrm{R}_{2}$ & $\mathrm{R}_{3}$ & $\mathrm{R}_{4}$ & $\mathrm{R}_{5}$ & $\mathrm{R}_{6}$ & $\mathrm{R}_{7}$ \\
\hline 35 & $\mathrm{H}$ & $\mathrm{H}$ & $\mathrm{Me}$ & $\mathrm{H}$ & $\mathrm{H}$ & $\mathrm{OH}$ & $\mathrm{H}$ \\
36 & $\mathrm{OH}$ & $\mathrm{Me}$ & $\mathrm{H}$ & $\mathrm{OMe}$ & $\mathrm{H}$ & $\mathrm{H}$ & $\mathrm{H}$ \\
37 & $\mathrm{H}$ & $\mathrm{H}$ & $\mathrm{H}$ & $\mathrm{H}$ & $\mathrm{OH}$ &
\end{tabular}<smiles>O=C1OCC23CCCCC2CC(O)C=C1C(=O)O3</smiles>

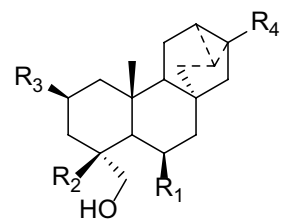

\begin{tabular}{l|llll} 
& $\mathrm{R}_{1}$ & $\mathrm{R}_{2}$ & $\mathrm{R}_{3}$ & $\mathrm{R}_{4}$ \\
\hline $\mathbf{4 2}$ & $\mathrm{OH}$ & $\mathrm{Me}$ & $\mathrm{H}$ & $\mathrm{CH}_{2} \mathrm{O}$ \\
$\mathbf{4 3}$ & $\mathrm{OH}$ & $\mathrm{Me}$ & $\mathrm{OH}$ & $\mathrm{Me}$ \\
$\mathbf{4 4}$ & $\mathrm{OH}$ & $\mathrm{OH}$ & $\mathrm{H}$ & $\mathrm{Me}$ \\
$\mathbf{4 5}$ & $\mathrm{H}$ & $\mathrm{OH}$ & $\mathrm{OH}$ & $\mathrm{Me}$ \\
$\mathbf{4 6}$ & $\mathrm{OH}$ & $\mathrm{OH}$ & $\mathrm{OH}$ & $\mathrm{Me}$
\end{tabular}

Fig. 2 Chemical structures of the compounds tested; 25, 5,7-dihydroxy-3,4-dimethoxyflavone; 26, 3,5,4'-trihydroxy-7 methoxyflavone; 27, 5,7-dihydroxy-3,6,4'-trimethoxyflavone; $\mathbf{2 8}$, 5,4'-dihydroxy-3,7-dimethoxyflavone; $\mathbf{2 9}$, 5-hydroxy-3,7,4'-trimethoxyflavone; 30, 3,5,6,7,4'-pen-

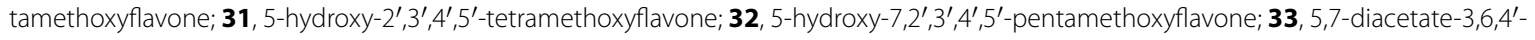
trimethoxyflavone; 34, 5,7-diacetate-3,4'-trimethoxyflavone; 35, 5,4'-dihydroxy-7-methoxyflavanone; 36, 3,7-dihydroxy-5,8-dimethoxyflavanone; 37, 5,7,4'-trihydroxy-3'-prenylflavanone; 38, dodonic acid; 39, hautriwaic acid; 40, $2 \beta$-hydroxyhardwickiic acid; 41, hautriwaic acid lactone; $\mathbf{4 2}$, 6,17,19-trachylobanetriol; (ent-6a)-form; 43, 2,6,19-trachylobanetriol; (ent-2a,6a)-form; 44, 6,18,19-trachylobanetetrol; (ent-6a)-form; 45, 2,18,19-trachylobanetriol; (ent-2a)-form; 46, 2,6,18,19-trachylobanetetrol; (ent-2ß,6a)-form; 47, ent-kaur-16-en-2a, 18,19-triol; 48, ent-kaur-16-en-18,19-diol

2010). Compound 1 was inactive against all drug sensitive and resistant bacteria. However, 2 with a similar skeletal structure as 1 except for the presence of an hydroxyl group at C6 was more active exhibiting antimicrobial activities against Gram-negative E. coli A102 and AG 100ATet; K. pneumoniae KP55, KP63, E. aerogenes EA289 with MIC values of 128, 16, 32, 128 and $128 \mu \mathrm{g} / \mathrm{mL}$, respectively. This anthraquinone showed good activities against MRSA 4, 6 and 8 with MIC values of 4 (vs 8 ), 4 (vs 64), 4 (vs 32 ) $\mu \mathrm{g} / \mathrm{mL}$, respectively, more active than the standard drug, chloramphenicol.
These results are comparable to those obtained by Hatano et al. (1999), where emodin exhibited noticeable antibacterial effects against four MRSA strains (OM481, OM505, OM584, OM623) and one MRSA strain (209P) with MIC values of about $64 \mu \mathrm{g} / \mathrm{mL}$ but less sensitive against the Gram-negative strains, E. coli $\mathrm{K} 12$ and Pseudomonas aeruginosa PA01 with MIC $>128 \mu \mathrm{g} / \mathrm{mL}$. The presence of an hydroxyl group in place of a methyl group at $\mathrm{C} 3$ or a methyl in place of hydroxyl group at $\mathrm{C} 8$ and an additional methyl ester (COOMe) group at $\mathrm{C} 7$ in 3 substantially reduced antimicrobial activities especially 
Table 1 Bacterial strains and features

\begin{tabular}{|c|c|c|}
\hline Bacterial strain & Relevant features & Reference \\
\hline \multicolumn{3}{|l|}{ Escherichia coli } \\
\hline ATCC 8739 and ATCC 10536 & Reference strains & \\
\hline AG100 & Wild-type E. coli K-12 & Viveiros et al. (2005) \\
\hline AG100ATet & $\triangle \mathrm{acr} A B$ mutant of $\mathrm{AG} 100 ; \mathrm{TET}^{\mathrm{R}}$ owing to acrF gene markedly overexpressed & Elkins and Mullis (2007) \\
\hline AG102 & AG100 over-expressing AcrAB pump & \\
\hline \multicolumn{3}{|l|}{ Enterobacter aerogenes } \\
\hline ATCC 13048 & Reference strain & \\
\hline EA-CM64 & CHLR variant obtained from & Ghisalberti et al. (2005) \\
\hline \multirow[t]{4}{*}{ EA3 } & ATCC 13048 overexpressing AcrAB pump & Pradel and Pagès (2002) \\
\hline & Clinical MDR isolate exhibiting energy-dependent & \\
\hline & Norfloxacin and chloramphenicol efflux with $\mathrm{KAN}^{R} \mathrm{AMP} \mathrm{P}^{\mathrm{R}}$ & \\
\hline & $N A L^{R} S T R^{R} T E T^{R}$ & \\
\hline \multirow[t]{4}{*}{ EA27 } & Clinical MDR isolate exhibiting & \\
\hline & Energy-dependent NOR and & \\
\hline & CHL efflux; KAN ${ }^{R} A M P^{R} N A L^{R}$ & \\
\hline & $S T R^{R} T E T^{R}$ & \\
\hline EA289 & KAN-sensitive derivative of EA27 & \\
\hline EA294 & EA289 acrA::KAN ${ }^{R}$ & \\
\hline EA289 & EA289 tolC::KAN ${ }^{R}$ & \\
\hline \multicolumn{3}{|l|}{ Klebsiella pneumoniae } \\
\hline ATCC 11296 & Reference strain & \\
\hline Kp55 & Clinical MDR isolate, $\mathrm{TET}^{R}$ & Chevalier et al. (2000) \\
\hline \multirow[t]{3}{*}{ Kp63 } & $\mathrm{AMP}^{R} \mathrm{ATM}^{R} C E F^{R}$ & \\
\hline & Clinical MDR isolate, $\mathrm{TET}^{\mathrm{R}} \mathrm{CHL}^{\mathrm{R}}$ & \\
\hline & $\mathrm{AMP}^{R} \mathrm{ATM}^{R}$ & \\
\hline \multicolumn{3}{|l|}{ Pseudomonas aeruginosa } \\
\hline PA01 & Reference strain & \\
\hline PA124 & MDR clinical isolate & Lorenzi et al. (2009) \\
\hline \multicolumn{3}{|l|}{ Staphyloccocus aureus } \\
\hline ATCC1026 & Reference strain & \\
\hline SA3 & Clinical Laboratory isolate, sensitive to methicilin & \\
\hline \multicolumn{3}{|l|}{ SA4 } \\
\hline \multicolumn{3}{|l|}{ SA11 } \\
\hline SA12 & Clinical laboratory isolate, $\mathrm{MET}^{\mathrm{R}}$ & \\
\hline MRSA 3 & & Dzoyem et al. (2013) \\
\hline \multicolumn{3}{|l|}{ MRSA 4} \\
\hline \multicolumn{3}{|l|}{ MRSA 6} \\
\hline MRSA 8 & & \\
\hline
\end{tabular}

KAN kanamycin, TET tetracycline, CHL chloramphenicol, NOR norfloxacin, AMP ampicillin, MET methicillin, NAL nalidixic acid, STR streptomycin, ATM aztreonam, CEF cefalothin, $R$ resistant, MDR multidrug-resistant

against the MRSA phenotype, as this compound did not inhibit these bacteria. However, this compound exhibited minimal antimicrobial activities against the standard E. coli ATCC8739 strain with MIC values of $256 \mu \mathrm{g} / \mathrm{mL}$, which was not inhibited by 2 . Compound 4 , which is a derivative of $\mathbf{3}$ with a slightly different skeletal structure in ring A had antimicrobial activities similar to those of 3, probably due to the total number of hydroxyl groups
(3), methyl (1) and acetate irrespective of the positions of these substituents in the anthroquinone skeleton. Furthermore, the substitution pattern of ring $\mathrm{C}$ was similar in the two compounds. This compound was also inactive against all bacteria strains tested except for the reference E. coli ATCC8939 strain with a MIC value of $256 \mu \mathrm{g} / \mathrm{mL}$.

The naphthoquinone, plumbagin (5) was active against both Gram-positive and Gram-negative bacteria tested 


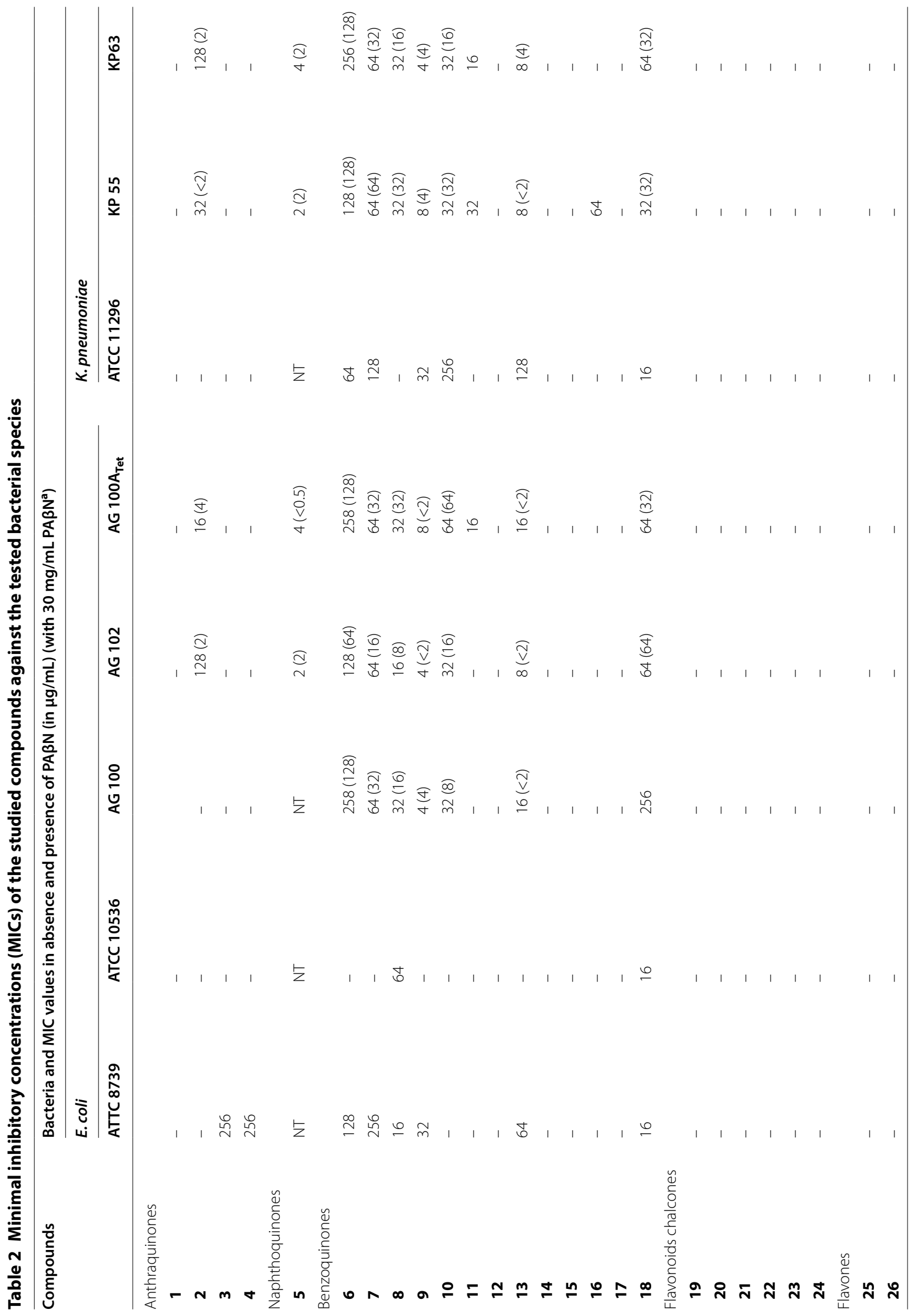




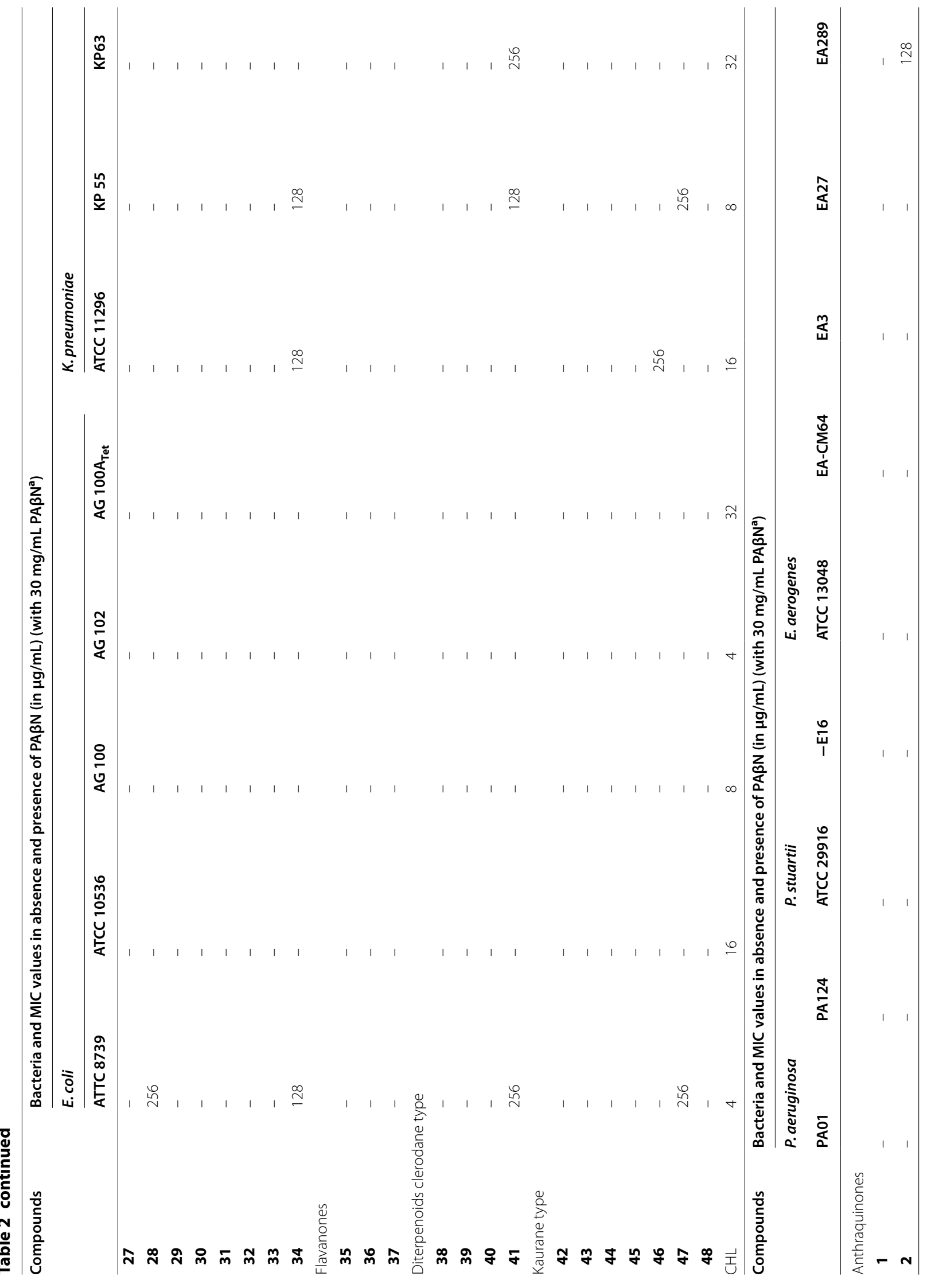




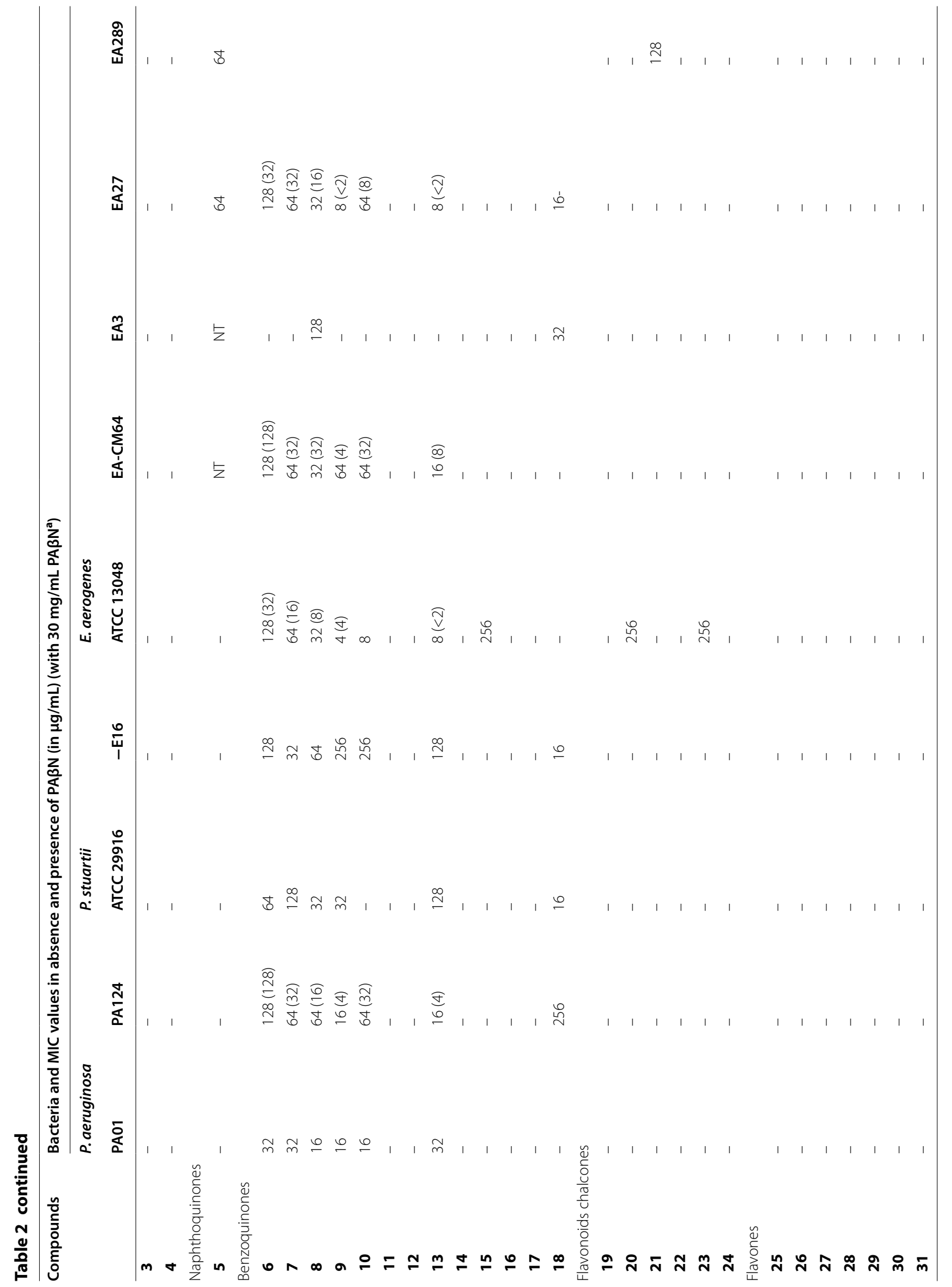




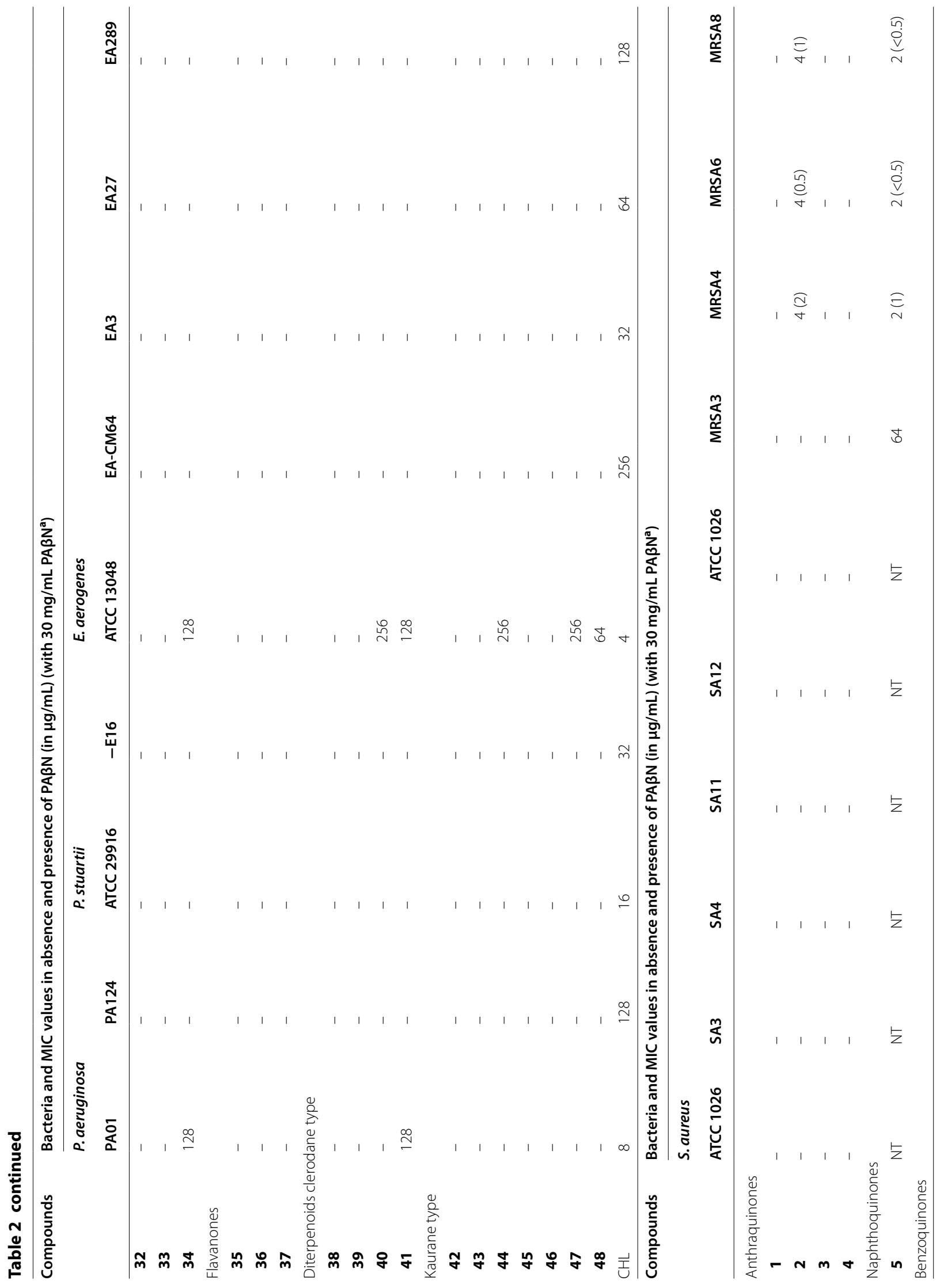




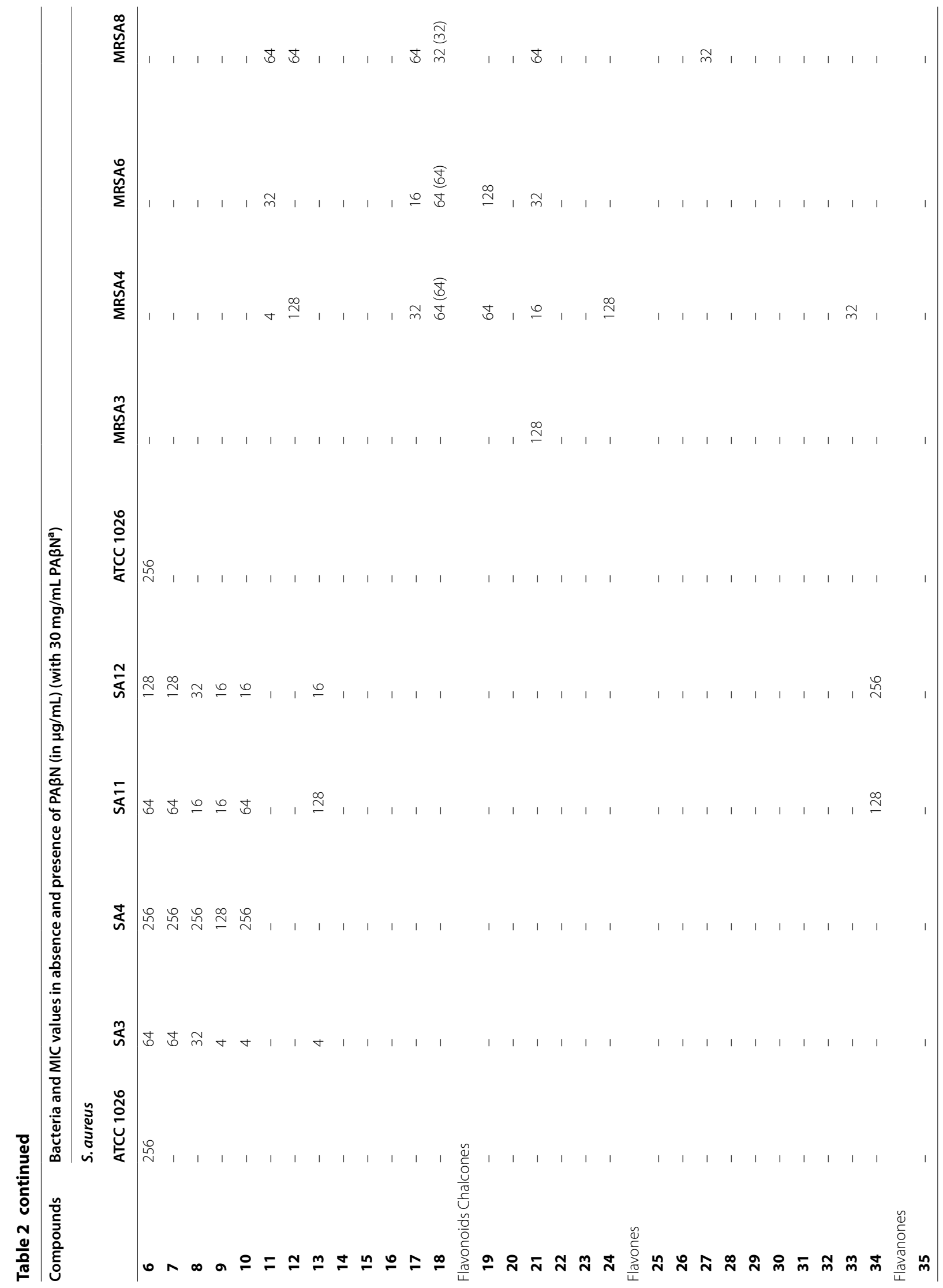




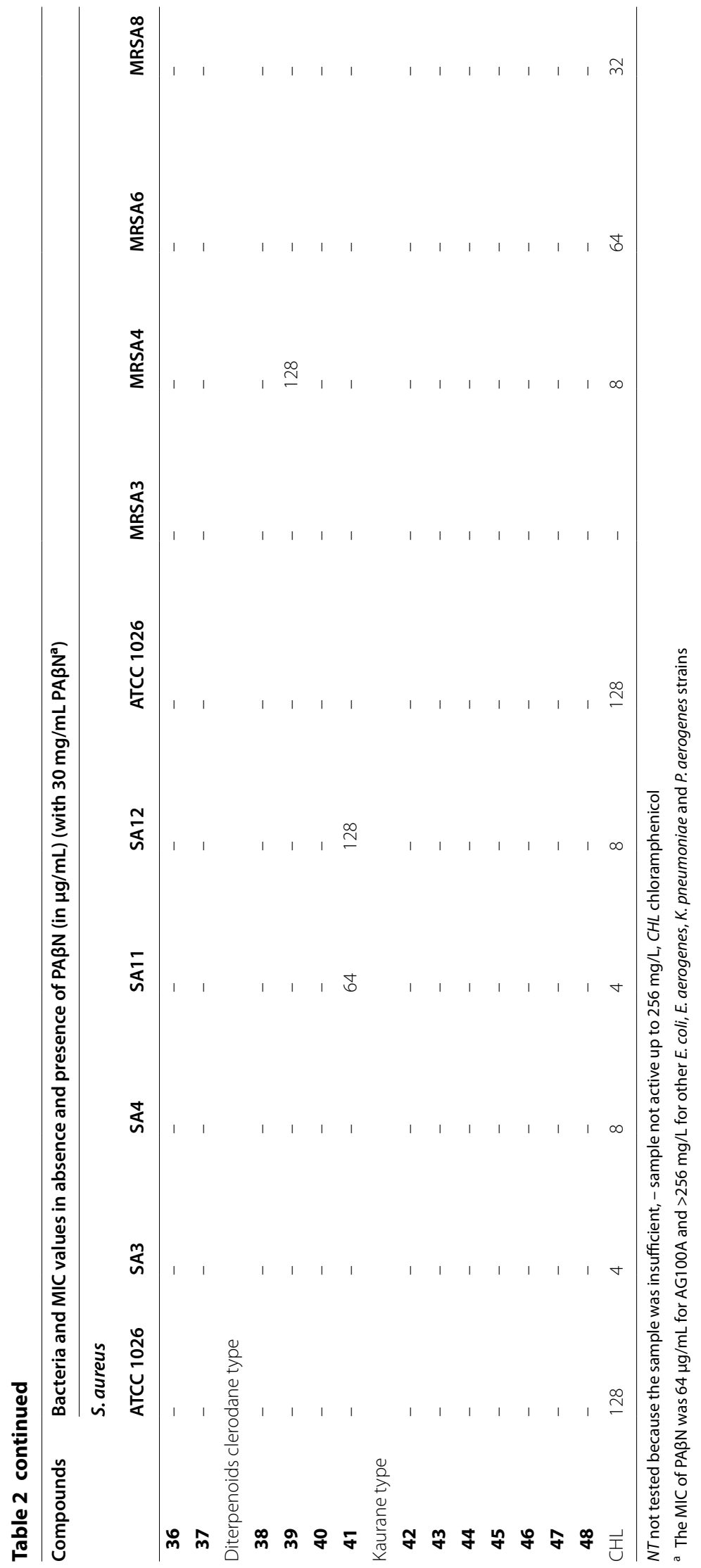


with interesting MIC values ranging from 2 to $64 \mu \mathrm{g} / \mathrm{mL}$. This naphthoquinone exhibited exceptionally good antimicrobial activities against MRSA 3, 4, 6, 8 compared to chloramphenicol with MIC values of 64 (vs $>256$ ), 2 (vs 8), 2 (vs 64) and 2 (vs 32) $\mu \mathrm{g} / \mathrm{mL}$, respectively. The good antibacterial activity of this compound is consistent to data previously documented (Kuete et al. 2011). Several studies have also demonstrated the potencies of plumbagin against bacteria and fungi (Brice 1955; Durga et al. 1990; Gujar 1990) as well as cancer (Melo et al. 1974). In a separate study the in vitro antimicrobial activities of plumbagin against selected microorganisms were reported to be significantly higher than the standard drug, streptomycin (Jeyachandran et al. 2009). The antibacterial potencies of different related benzoquinones were established against both Gram-negative and Grampositive bacteria strains. Compounds 6-8 with a 2-4 carbon alkyl side chain revealed similar activities against various microbes with MIC ranging from 16 to $256 \mu \mathrm{g} /$ $\mathrm{mL}$. There was a marked improvement of antibacterial activities with increasing length of the lipophilic chain to 7 as shown by 9 exhibiting low MIC values ranging from 4 to $32 \mu \mathrm{g} / \mathrm{mL}$.

There was reduced antimicrobial activities with compounds 10 (C9) against most bacteria strains with the lowest activity recorded having MIC $\geq 256 \mu \mathrm{g} / \mathrm{mL}$ against E. coli ATCC 8739, AG102, AG100A ${ }_{\mathrm{Tet}}$; S. aureus A4, A11; K. pneumoniae ATCC11296, KP63; P. stuartii ATCC29916, NAE16; E. aerogenes EA27 and against all strains of MRSA. The activities of compound 11 (C13) against specific bacteria was comparable to that of 9 especially against the Gram-negative E. coli AG100A $_{\text {Tet, }}$, $K$. pneumoniae KP55, KP63 with MIC values ranging from 16 to $32 \mu \mathrm{g} / \mathrm{mL}$.

This compound exhibited selective activities against specific Gram-negative bacteria such as E. coli AG100ATet, K. pneumoniae KP55, KP63 and the Gram-positive MRSA 4, 6, 8 some of which were more potent than chloramphenicol (Table 2).

Increasing chain lengths of the alkyl group from $\mathrm{C} 15$ in compound 12 to C19 in 15-17 had no effect on further improving the activities of compound $\mathbf{1 1}$ (C13) against most bacteria. However, 17 showed selective activities against three strains of MRSA including MRSA4, 6 and 8. Reduction of the two keto groups of $\mathbf{1 5}$ and subsequent acetylation at $C 1,2,4,5$ positions as seen in 17 improved the antibacterial activities against specific bacteria including MRSA 4, 6, 8. The MIC values of 17 against MRSA4 and 8 strains were observed to be almost as low as those of the standard drug with MIC values of 32 (vs 8 ) and 64 (vs 32), respectively (Table 2) while that against MRSA6 was more active than the standard drug (16 (vs 64) $\mu \mathrm{g} / \mathrm{mL}$. This observation could imply that increasing the chain length up to $\mathrm{C} 7$ probably results in more profound antibacterial activities. Further increases in chain length had little effect on the improvement of the antibacterial activities but led to selectivity of the drugs towards specific bacteria, as seen in 11-13. The alkyldibenzoquinone, ardisiaquinone B (18) with two benzoquinone rings at the end of the alkyl chain (C16) showed improved activities as compared to the monomeric benzoquinone with a similar number of carbon atoms in the lipophilic chain. This compound showed interesting activities against all strains of E. coli, K. pneumoniae, $P$. staurtii and MRSA. This compound was also potent against $P$. aeruginosa PA124 and E. aerogenes EA27 but seemed to be inactive against Gram-positive $S$. aureus.

Compound 19 with two hydroxyl groups, one at $\mathrm{C} 3$ 'and the other in meta orientation at $\mathrm{C}^{\prime}$ and one methoxy group also in meta orientation to the hydroxyl group at $\mathrm{C}^{\prime}$ ', without a substituent at $\mathrm{C} 2^{\prime}$ was active against two strains of MRSA 4 and 6 . However, interchanging the hydroxyl group at $\mathrm{C}^{\prime}$ for a methoxy group and vice versa completely reduced the antimicrobial activities against these two MRSA strains. This may imply that the substitution pattern of the substituents on ring $B$ where at least one hydroxyl group is placed at $\mathrm{C}^{\prime}$, an additional hydroxyl groups in meta orientation (either at $\mathrm{C}^{\prime}$ and $5^{\prime}$ ), a methoxy group in meta orientation to the $\mathrm{C}^{\prime}$ hydroxyl group (either at $\mathrm{C}^{\prime}$ and $5^{\prime}$ ) as observed in 19 (hydroxyl at $\mathrm{C}^{\prime}$, one meta position to have methoxy and the other hydroxyl) is important for minimal activities against the two strains of MRSA. Compound 21 with two methoxy groups and two hydroxyl groups in meta orientation was the most active compound of the evaluated chalcones; against the four MRSA strains. The increased antibacterial activities of this compound could be attributed to the additional oxygenation at $\mathrm{C}^{\prime}$ position. The basic requirement for activities against MRSA strains (hydroxyl at C3', one meta position to have methoxy and the other hydroxyl) was observed here too. However, more studies need to be undertaken to understand the active scaffold in the chalcone skeleton. Compound 22 with one hydroxyl group at $\mathrm{C}^{\prime}$ and two methoxy groups at $\mathrm{C}^{\prime}{ }^{\prime}$ and $\mathrm{C}^{\prime}{ }^{\prime}$ did not exhibit any antibacterial activities against all the strains of bacteria including MRSA most probably due to the lack of the required scaffold. Compound 23 with two hydroxyl group in meta position in ring A but was lacking a methoxy group in second meta position was inactive against all bacteria tested including the MRSA strains, except for the Gram-negative E. aerogenes, ATCC13048, with minimal activity.

Most of the flavones tested were polymethoxylated making them lipophilic and therefore showing minimal or no activities against the bacteria tested. Previous studies have shown that antifungal compounds tend to be 
more lipophilic compared to antibacterial compounds and hence these compounds should be tested for their antifungal potential (McClure 1975; Omosa et al. 2014). Compound 34 showed minimal activities against specific bacteria strains with MIC values ranging from 128 to $256 \mu \mathrm{g} / \mathrm{mL}$ most probably due to increase in hydrophilicity (Omosa et al. 2014). The flavanones tested were also inactive due to their lipophilicity as shown in previous studies. The clerodanediterpenoids were inactive against all bacteria tested except for hautriwaic acid (Omosa et al. 2014) which showed minimal activity against some bacterial strains. However, its lactone did not exhibit antimicrobial activities $\leq 256 \mu \mathrm{g} / \mathrm{mL}$, most probably because of increased lipophilicity. The presence of a free hydroxyl group at C19 in the clerodane skeleton appears to be necessary for minimal activities against $S$. aureus SA 11, 12; K. pneumoniae KP55, 63; P. aeroginosa PA01 and E. aerogenes ATCC 13048 strains. The kaurane type diterpenoids exhibited similar antimicrobial profile as the clerodanes which could be attributed to their lipophilicity.

Role of efflux pumps in the susceptibility of tested bacteria In this study the compounds that attained certain threshold of activities including the anthraquinone, 2; naphthaquinone, 5; and some benzoquinones, 6-10, 13 and 18 were combined with the efflux pump inhibitor, EPI, $\mathrm{PA} \beta \mathrm{N}$, in order to assess the involvement of efflux in the activities of these compounds. When tested alone compound 2 showed minimal antibacterial activities against some Gram-negative MDR strains including E. coli AG100 and 102, as well as K. pneumoniae KP 55 and K63 (Table 2). However, there was substantial enhancement of activities of 2 with PA $\beta \mathrm{N}$. The observed MICs without $\mathrm{PA} \beta \mathrm{N}$ against $E$. coli AG102, $100 \mathrm{~A}_{\mathrm{Te}} \dot{ } ; \mathrm{K}$. pneumoniae $\mathrm{KP}$ 55 and $K 63$ were $128,16,32,128 \mu \mathrm{g} / \mathrm{mL}$. With PA $\beta \mathrm{N}$ the activities improved by $>4$ fold, exhibiting MICs higher than the standard, chloramphenicol of $2,4,<2$ and $2 \mu \mathrm{g} /$ $\mathrm{mL}$, respectively (Table 2 ). This compound which exhibited good antibacterial activities against MDR Grampositive bacteria alone also showed improved activities in combination with PA $\beta \mathrm{N}$. However, the improvement was not as substantial as that observed against the Gramnegative bacteria. The naphthaquinone, plumbagin (5) which showed good activities even when tested alone exhibited minimal improvement with $\mathrm{PA} \beta \mathrm{N}$ as compared to emodin (2) except against $\mathrm{AG}_{100 \mathrm{~A}_{\text {Tet }}}$ with $>8$ fold increament. These results consistent with those obtained by Kuete et al. (2011). The antimicrobial activities against the Gram-positive MDR strains increased by $>4$ fold against MRSA 6, 8 and $>2$ fold for MRSA 4.

The benzoquinones, 6-10 and 18 showed enhancement in activity with $\mathrm{PA} \beta \mathrm{N}$ most of which were $>2$ and
4 folds, with 13 having MICs $<10 \mu \mathrm{g} / \mathrm{mL}$. These data clearly demonstrate that the quinones and chalcones tested are substrates of bacterial efflux pumps and should be combined to EPI in the fight against MDR bacterial infections. The obtained results are therefore consistent to data previously reported by Kuete et al. (2011), who highlighted the role of efflux pumps in the bacterial resistance to natural products.

\section{Conclusion}

In this study, various anthraquinones, naphthoquinones, benzoquinones, flavonoids (chalcones and polymethoxylated flavones) and diterpenoids (clerodanes and kauranes) were explored for their antimicrobial potential against different drug sensitive Gram-negative and Gram-positive bacteria.

The results show that the anthraquinone (2), naphthaquinone, plumbagin (5) benzoquinones $(11,12,17$, 18), chalcones $(19,21)$ were active against MRSA bacteria strains with MIC value ranging from 2 to $128 \mu \mathrm{g} /$ $\mathrm{mL}$. Structure activity relationships of benzoquinones; which has not been carried out in previous studies, showed that antibacterial activities gradually increased with increasing side chain length from 2, 3, 4 for $\mathbf{6}, 7$ and $\mathbf{8}$, respectively, with optimal activities being realized with C7 (9). This study also showed that there is a minimum chain length that is required for maximum activity in the 2,5 dihydroxy-1,4-benzoquinone moieties. This studies showed that the minimum chain length required for optimal antimicrobial activities was C7 (compound 9) beyond which no marked activity improvement has been observed. Some compounds selectively inhibited the growth of specific but not all bacteria. These studies revealed that the presence of a hydroxyl group at $\mathrm{C} 3^{\prime}$ together with a methoxy group and a second hydroxyl group in meta orientation in ring $B$ of the chalcone skeleton appears to be necessary for minimal activities against MRSA 4 and 6 as elaborated in 19-24.

These data clearly demonstrate that the tested compounds are substrates of bacterial efflux pumps and should be combined to EPI in the fight against MDR bacterial infections. The obtained results are therefore consistent to data previously reported by Kuete et al. (2011), who highlighted the role of efflux pumps in bacterial resistance to natural products.

\section{Methods}

\section{Reagents and compounds}

The chemicals used in antimicrobial assays were chloramphenicol $\geq 98 \%$ (Sigma-Aldrich, St-Quentin-Fallavier, France) as reference antibiotic and $p$-Iodonitrotetrazolium chloride $\geq 97 \%$ (INT, Sigma-Aldrich) as microbial growth indicator (Eloff 1998; Mativandlela et al. 2006). 
Phenylalanine-Arginine- $\beta$-Naphthylamide $\quad(\mathrm{PA} \beta \mathrm{N}$; Sigma-Aldrich) was used as efflux pumps inhibitor (EPI). Natural products (Figs. 1, 2) used in the study were obtained from the chemical bank of the natural products research laboratory of the Chemistry Department, University of Nairobi, Kenya. Isolation and identification of the compounds in study were previously reported from the following plants; a number of Rumex species including; Rumex dentatus, $R$. abyssinicus, $R$. usambarensis, $R$. bequaertii, R. ruwenzoriensis, $R$. crispus; Plumbago zeylanica, Myrsine africana, Maesa lanceolata, Rapanea melanphloes, Aloe saponaria, Erythrina abyssinica, Polygonum senegalense, Psiadia punctulata, Dodonaea angustifolia and Senecio roseiflorus.

\section{Bacterial strains and culture media}

MDR isolates and reference strains of Escherichia coli, Enterobacter aerogenes, Pseudomonas aeruginosa, Klebsiella pneumoniae and Staphylococcus aureus are summarized in Table 1. Isolates were conserved at $4{ }^{\circ} \mathrm{C}$ and were grown on Mueller-Hinton agar for $24 \mathrm{~h}$ before minimal inhibitory concentration (MIC) testing. Mueller-Hinton broth (MHB) was used for the susceptibility tests (Kuete et al. 2008).

\section{Determination of bacterial susceptibility}

The MIC determinations on the tested bacteria were conducted using rapid INT colorimetric assay according to described methods (Eloff 1998) with some modifications (Kuete et al. 2007, 2009). First of all, the test samples and reference antibiotic (RA) were dissolved in dimethyl sulphoxide (DMSO)/Mueller-Hinton Broth (MHB) or DMSO/MHB broth. The final concentration of DMSO was lower than $2.5 \%$ and does not affect the microbial growth. The solution obtained was then added to $\mathrm{MHB}$, and serially diluted two fold (in a 96-wells microplate). One hundred microlitrer $(100 \mu \mathrm{L})$ of inoculum $1.5 \times 10^{6} \mathrm{CFU} / \mathrm{mL}$ prepared in appropriate broth was then added. The plates were covered with a sterile plate sealer, then agitated to mix the contents of the wells using a plate shaker and incubated at $37{ }^{\circ} \mathrm{C}$ for $18 \mathrm{~h}$. Wells containing adequate broth, $100 \mu \mathrm{L}$ of inoculum and DMSO to at a final concentration of $2.5 \%$ served as negative control. Choramphenicol was used as a RA. The minimum inhibition concentration (MIC) of samples was detected after $18 \mathrm{~h}$ incubation at $37{ }^{\circ} \mathrm{C}$, following addition $(40 \mu \mathrm{L})$ of $0.2 \mathrm{mg} / \mathrm{mL}$ of INT and incubation at $37{ }^{\circ} \mathrm{C}$ for $30 \mathrm{~min}$. Viable bacteria reduced the yellow dye (TNT) to pink. MIC was defined as the sample concentration that prevented the color change of the medium and exhibited complete inhibition of microbial growth (Eloff 1998). All assays were carried out in triplicate and were repeated three times. To evaluate the role of efflux pumps in the susceptibility of Gram-negative bacteria to the most active compounds, they were tested in the presence of PAßN (at $30 \mu \mathrm{g} / \mathrm{mL}$ ) against selected MDR phenotypes (Table 2) and MICs were determined as mentioned above.

\section{Authors' contributions}

LKO, wrote the manuscript and carried out some phytochemical studies; JI carried out some of the phytochemical work; JOM supervised most of the phytochemical work; ATM, SBT and JAS, IKV and JKD designed and carried out the bioassay experiments; SD, TE and RAO edited the manuscript. VK supervised the antibacterial assays and provided the facilities and reagents for the study. All authors read and approved the final manuscript.

\section{Author details \\ ${ }^{1}$ Department of Chemistry, School of Physical Sciences, University of Nai- robi, P. O. Box 30197-00100, Nairobi, Kenya. ${ }^{2}$ Department of Biochemistry, Faculty of Science, University of Dschang, Dschang, Cameroon. ${ }^{3}$ Department of Pharmaceutical Biology, Institute of Pharmacy and Biochemistry, Johannes Gutenberg University, Staudinger Weg 5, 55128 Mainz, Germany.}

\section{Acknowledgements}

The authors would like to sincerely thank the German Academic Exchange Service (DAAD) for financial support of part of this work. A Grant for this research was also provided by the Deutsche Forschungsgemeinschaft, Germany, Grant No. Pe 264/14-5 and by the Bundesministerium für Zusammenarbeit, Grant No. Pe-254/14-6. A Grant for part of this work was also provided by International Science Programme, Uppsala University, Sweden (ISP) through the KEN-02 project. The authors wish to thank Mr. Simon Mathenge and Mr. Patrick Chalo Mutiso for the identification and collection of the plant materials from which the compounds were isolated.

\section{Competing interests}

The authors declare that they have no competing interests.

Received: 28 January 2016 Accepted: 16 June 2016

Published online: 27 June 2016

\section{References}

Alekshun MN, Levy SB (2007) Molecular mechanisms of antibacterial multidrug resistance. Cell 128(6):1037-1050

Brice HE (1955) Antibacterial substances produced by flowering plants. Aust J Exp Biol Med 33:547-554

Chang CH, Lin CC, Yang JJ, Namba T, Hattori M (1996) Anti-inflammatory effects of emodin from ventilago leiocarpa. Am J Chin Med 24(02):139-142

Chevalier J, Pagès J-M, Eyraud A, Malléa M (2000) Membrane permeability modifications are involved in antibiotic resistance in Klebsiella pneumoniae. Biochem Biophys Res Commun 274:496-499

Dagne E, Casser I, Steglich W (1992) Aloechrysone, a dihydroanthracenone from Aloe berhana. Phytochem 31(5):1791-1793

Dagne E, Van Wyk B-E, Mueller M, Steglich W (1996) Three dihydroanthracenones from Gasteria bicolor. Phytochem 41(3):795-799

Davin-Regli A, Bolla JM, James CE, Lavigne JP, Chevalier J, Garnotel E, Molitor A (2008) Membrane permeability and regulation of drug "influx and efflux" in enterobacterial pathogens. Curr Drug Targets 9(9):750-759

De Clercq E (2001) New developments in anti-HIV chemotherapy. Pharmacol $56: 3-12$

Durga R, Sridhar P, Polasa H (1990) Effect of plumbagin on antibiotic resistance in bacteria. Indian J Med Res 91:18-20

Dzoyem JP, Hamamoto H, Ngameni B, Ngadjui BT, Sekimizu K (2013) Antimicrobial action mechanism of flavonoids from Dorstenia species. Drug Discov Ther 7(2):66-72

Elkins CA, Mullis LB (2007) Substrate competition studies using whole-cell accumulation assays with the major tripartite multidrug efflux pumps of Escherichia coli. Antimicrob Agents Chemother 51:923-929 
Eloff JN (1998) A sensitive and quick microplate method to determine the minimal inhibitory concentration of plant extracts for bacteria. Planta Med 64:711-713

Fairbairn JJW, El-Muhtadi FJ (1972) Chemotaxonomy of anthraquinones in Rumex. Phytochem 11(1):263-268

Ghisalberti D, Masi M, Pagès J-M, Chevalier J (2005) Chloramphenicol and expression of multidrug efflux pump in Enterobacter aerogenes. Biochem Biophys Res Commun 328:1113-1118

Gujar GT (1990) Plumbagin, a naturally occurring naphthoquinone. Its pharmacological and pesticidal activity. Fitoterapia 59:387-393

Hatano T, Uebayashi H, Ito H, Shiota S, Tsuchiya T, Yoshida T (1999) Phenolic constituents of Cassia seeds and antibacterial effect of some naphthalenes and anthraquinones on methicillin-resistant Staphylococcus aureus. Chem Pharm Bull 47(8):1121-1127

Jeu L, Piacenti FJ, Lyakhovetskiy AG, Fung HB (2003) Voriconazole. Clin Ther 25(5):1321-1381

Jeyachandran R, Mahesh A, Cindrella L, Sudhakar S, Pazhanichamy K (2009) Antibacterial activity of Plumbagin and root extracts of Plumbago zeylanica L. Acta Biol Cracov Bot 51(1):17-22

Juma BF, Yenesew A, Midiwo JO, Waterman PG (2001) Flavones and phenylpropenoids in the surface exudate of Psiadia punctulata. Phytochem 57(4):571-574

Juma BF, Midiwo JO, Yenesew A, Waterman PG, Heydenreich M, Peter MG (2006) Three ent-trachylobane diterpenes from the leaf exudates of Psiadia punctulata. Phytochem 67(13):1322-1325

Kerubo LO, Midiwo JO, Derese S, Langat MK, Akala HA, Waters NC, Peter M, Heydenreich M (2013) Antiplasmodial activity of compounds from the surface exudates of Senecio roseiflorus. Nat Prod Commun 8(2):175-176

Khurana SK, Krishnamoorthy V, Seshadri TR (1972) Mass spectral analysis of the pigments from Embelia ribes and Connarus monocarpus Linn. Cur Sci 41:331-332

Kimberlin DW, Whitley RJ (1996) Anti-viral resistance: mechanisms, clinical significance, and future implications. J Antimicrob Chemother 37:403-421

Kuete V (2010) Potential of Cameroonian plants and derived products against microbial infections: a review. Planta Med 76:1479-1491

Kuete V, Efferth T (2010) Cameroonian medicinal plants: pharmacology and derived natural products. Front Pharmacol 1:123

Kuete V, Wabo GF, Ngameni B, Mbaveng AT, Metuno R, Etoa F-X, Ngadjui BT, Beng VP, Meyer JJM, Lall N (2007) Antimicrobial activity of the methanolic extract, fractions and compounds from the stem bark of Irvingia gabonensis (Ixonanthaceae). J Ethnopharmacol 114(1):54-60

Kuete V, Wansi JD, Mbaveng AT, Sop MK, Tadjong AT, Beng VP, Etoa F-X, Wandji J, Meyer JJM, Lall N (2008) Antimicrobial activity of the methanolic extract and compounds from Teclea afzelii (Rutaceae). S Afr J Bot 74:572-576

Kuete V, Nana F, Ngameni B, Mbaveng AT, Keumedjio F, Ngadjui BT (2009) Antimicrobial activity of the crude extract, fractions and compounds from stem bark of Ficus ovata (Moraceae). J Ethnopharmacol 124:556-561

Kuete V, Alibert-Franco S, Eyong KO, Ngameni B, Folefoc GN, Nguemeving JR, Tangmouo JG, Fotso GW, Komguem J, Ouahouo BMW, Bolla J-M, Chevalier J, Ngadjuic BT, Nkengfack AE, Pagès J-M (2011) Antibacterial activity of some natural products against bacteria expressing a multidrug-resistant phenotype. Int J Antimicrob Ag 37:156-161

Lorenzi V, Muselli A, Bernardini AF, Berti L, Pagès JM, Amaral L (2009) Geraniol restores antibiotic activities against multidrug-resistant isolates from Gram negative species. Antimicrob Agents Chemother 53:2209-2211

Manguro LOA, Midiwo JO, Kraus W, Ugi I (2003) Benzoquinone derivatives of Myrsine africana and Maesa lanceolata. Phytochem 64(4):855-862

Mativandlela SPN, Lall N, Meyer JJM (2006) Antibacterial, antifungal and antitubercular activity of (the roots of) Pelargonium reniforme (CURT) and Pelargonium sidoides (DC) (Geraniaceae) root extracts. S Afr J Bot 72:232-237

McClure JW (1975) Physiology and functions of flavonoids. The flavonoids. Springer, New York, pp 970-1055

Mehandale AR, Rao AR, Shaikh IN, Venkataraman K (1968) Desoxyerythrolaccin and laccaic acid D. Tetrahedron Lett 9(18):2231-2234

Melo AM, Jardim M, Santana C, Lacet Y, Filho J, Lima I, Leoncio OG (1974) First observations on the topical use of primin, plumbagin and mayteni in patients with skin cancer. Rev I Antibiot 14:9-16

Merian R, Schlittler E (1948) Über das vorkommen von Embelin in der Familie der Myrsinaceen. Helv Chim Acta 31(7):2237-2241

Midiwo JO, Rukunga GM (1985) Distribution of Anthraquinone Pigments in Rumex species of Kenya. Phytochem 24(6):1390-1391
Midiwo JO, Matasi JJ, Wanjau OM, Mwangi RW, Waterman PG, Wollenweber E (1990) Anti-feedant effects of surface accumulated flavonoids of Polygonum senegalense. B Chem Soc Ethiopia 4(2):123-127

Midiwo JO, Gikonyo NK, Wanjau DO, Matasi JJ, Waterman PG (1992) Flavonoids of Polygonum senegalense (Meisn) Part II: more surface and internal tissue flavonoid aglycones. B Chem Soc Ethiopia 6(2):119-122

Midiwo JO, Owuor FAO, Juma BF, Waterman PG (1997) Diterpenes from the leaf exudate of Psiadia punctulata. Phytochem 45(1):117-120

Munavu RM, Mudamba LO, Ogur JA (1984) Isolation and characterization of the major anthraquinone pigments from Rumex abysinica. Planta Med 50(1):111

Murthy VK, Rao TVP, Venkateswarlu V (1965) Chemical examination of Ardisia macrocarpa Wall. Tetrahedron 21(6):1445-1447

Nakahara K, Roy MK, Ono H, Maeda I, Ohnishi-Kameyama M, Yoshida M, Trakoontivakorn G (2003) Prenylated flavanones isolated from flowers of Azadirachta indica (the neem tree) as antimutagenic constituents against heterocyclic amines. J Agri Food Chem 51 (22):6456-6460

Nikaido H (2009) Multidrug resistance in bacteria. Annu Rev Biochem 78:119-146

Ogawa H, Natori S (1965) Hydroxybenzoquinones from Myrsinaceae Plants. I. Reconfirmation of the Structure of Maesaquinoes and Isolation of Acetylmaesaquinone from Maesa japonica MORITZI. Chem Pharm Bull 13(4):511-516

Ogawa H, Natori S (1968a) Hydroxybenzoquinones from myrsinaceae plants-II: distribution among myrsinaceae plants in Japan. Phytochem 7(5):773-782

Ogawa H, Natori S (1968b) Hydroxybenzoquinones from Myrsinaceae plants. III. The structures of 2-hydroxy-5-methoxy-3-pentadecenylbenzoquinone and Ardisiaquinones A, B and C from Ardisia spp. Chem Pharm Bull 16(9):1709-1720

Omosa LK, Midiwo JO, Derese S, Yenesew A, Peter MG, Heydenreich M (2010) neo-Clerodane diterpenoids from the leaf exudate of Dodonaea angustifolia. Phytochem Lett 3(4):217-220

Omosa LK, Amugune B, Ndunda B, Milugo TK, Heydenreich M, Yenesew A, Midiwo JO (2014) Antimicrobial flavonoids and diterpenoids from Dodonaea angustifolia. S Afr J Bot 91:58-62

Poole K (2001) Overcoming anti-microbial resistance by targeting resistance mechanisms. J Pharm Pharmacol 53:283-294

Pradel E, Pagès J-M (2002) The AcrAB-TolC efflux pump contributes to multidrug resistance in the nosocomial pathogen Enterobacter aerogenes. Antimicrob Agents Chemother 46:2640-2644

Sidhu GS, Sankaram A, Ali SM (1968) Extractives from Diospyros Species. 3. New Naphthaquinones + Naphthols from Heartwood of Diospyros melanoxyIon Roxb. Indian J Chem 6(12):681

Silver L, Bostian K (1990) Screening of natural products for anti-microbial agents. Eur J Cli Microbiol Infect Dis 9:455-461

Taylor PW, Stapleton PD, Luzio JP (2002) New ways to treat bacterial infections. Drug Discov Today 7:1086-1091

Viveiros M, Jesus A, Brito M, Leandro C, Martins M, Ordway D (2005) Inducement and reversal of tetracycline resistance in Escherichia coli K-12 and expression of proton gradient-dependent multidrug efflux pump genes. Antimicrob Agents Chemother 49:3578-3582

Wouters J, Verhecken A (1987) The chemical nature of flavokermesic acid. Tetrahedron Lett 28(11):199-1202

Wu L, Yang C, Yang L (2009) Synthesis of 2-hydroxy-5-methoxy-3-alkyl-1, 4-benzoquinones. Asian J Chem 21(9):7005

Yagi A, Yamanouchi M, Nishioka I (1978) Biosynthetic relationship between tetrahydroanthracene and anthraquinone in Aloe saponaria. Phytochem 17(5):895-897

Yoshihir K, Sakaki S, Ogawa H, Natori S (1968) Hydroxybenzoquinones from Myrsinaceae plants. 4. Further confirmation of structures of ardisiaquinones and some observations on alkylaminobenzoquinone derivatives. Chem Pharm Bull 16(12):2383

Yuan LIU, Chao LIU (2007) Determination the content of plumbagin in Plumbago zeylanica L. from different areas by RP-HPLC [J]. Chin Pharm J 18:019

Zhang H, Guo Z, Wu N, Xu W, Han L, Li N, Han Y (2012) Two novel naphthalene glucosides and an anthraquinone isolated from Rumex dentatus and their antiproliferation activities in four cell lines. Molecules 17(1):843-850 